\title{
Gordana BENCE
}

\section{Hibridni odprti javni prostor krajinskih elementov in grajene strukture}

\section{Hybrid open public space of landscape elements and built stucture}

$\checkmark$ Evropi in drugod lahko opazimo številne poskuse hibridnega združevanja krajinskih elementov in grajene strukture ter različnih rab prostora $v$ neločljivo celoto. Fizična in programska prepletenost krajinskih elementov in grajene strukture omogoča uporabnikom tega prostora različne dnevne rabe, kot so oddih in rekreacija ter doživljanje drugih prizorišč (kulturnih, izobraževalnih in socialnih), v pretežno s krajinskimi elementi urejenem javnem odprtem prostoru. Na podlagi opredeljenih družbenih sprememb in novih usmeritev $v$ načrtovanju urbanih območij, analiz primerov sodobne arhitekturne in urbanistične prakse z vidika vključevanja krajinskih elementov $v$ urbano strukturo so $\checkmark$ prispevku opredeljeni pojav hibridnega javnega odprtega prostora krajinskih elementov in grajene strukture ter metodološka izhodišča za načrtovanje sodobnih oblik javnega odprtega prostora.

KLJUČNE BESEDE: grajena struktura, hibridni javni odprti prostor, krajinski elementi, kakovostno bivalno okolje, urbano območje.

\section{Uvod}

Prispevek obravnava problematiko razkoraka znotraj trajnostne paradigme razvoja mest, ki je z vidika urbanističnega in arhitekturnega načrtovanja zaznamovana $\mathrm{z}$ dvema nasprotujočima si ciljema. $\mathrm{Na}$ eni strani je cilj urbanističnega in arhitekturnega načrtovanja z željo po ponovnem vzpostavljanju človekovega merila in preprečevanju nadaljnje širitve grajene strukture v zaledje mesta vse bolj usmerjen v kompaktno zgoščanje grajene strukture. Na drugi strani pa trajnostna paradigma $v$ urbanističnem načrtovanju poudarja pomen ohranjanja in varovanja območij krajine znotraj urbane strukture, ki prispevajo $\mathrm{k}$ vzpostavljanju kakovostnega bivalnega okolja. Nove usmeritve, ki so posledica iskanja odgovorov na stopnjo razvitosti družbe, zahtevajo nove pristope $\mathrm{k}$ načrtovanju urbanih območij, ki bodo na aplikativni ravni oblikovali takšno urbano strukturo, kjer bosta grajena struktura in odprti
The trend today in the cities in Europe and elsewhere is in combining landscape elements, built structure and different uses into a complex urban structure. Physical and program interweaving of landscape elements and built structure enables the consumers daily practice of leisure programs - relaxation, recreation and experiencing other cultural, educational and social events in the public green space. On the basis of determinate social changes and new approaches in urban planning practice, analyses of architectural and urban case studies from the point of view of integrating the landscape elements into the urban structure, the article defines the phenomenon of hybrid open public space and proposes methodical guidelines for the planning.

KEY WORDs: built structure, hybrid open public space, landscape elements, high-quality living environment, urban area.

prostor obravnavana enakovredno. Zgoščanje grajene strukture oziroma izraba površin $v$ urbanih območjih preoblikuje tipologijo grajene strukture in njen odnos do odprtega prostora, kar dodaja nove oblike $\mathrm{k}$ tradicionalnim oblikam javnega odprtega prostora, kot so trg, ulica in park. S prispevkom želimo odgovoriti na vprašanje, ki ga odpira trajnostni pristop k načrtovanju urbanih območij: kako lahko težnje po povečanju gostote prebivalcev v urbanih območjih soobstajajo s povečanjem kakovosti bivanja ter kako je $\mathrm{v}$ ta kompaktna poselitvena območja vključena krajina oziroma odprti prostor?

Nove oblike dejavnosti in sodobno življenje zahtevajo drugačne oblike zelenih površin oziroma parkov v urbanem prostoru. V Evropi in drugod lahko opazimo poskuse načrtovanja odprtih zelenih prostorov, ki s programsko in fizično povezavo $z$ grajeno strukturo ustvarjajo nove oblike hibridnih struktur. Pojav hibridnega odprtega javnega prostora je posledica 
iskanja odgovorov $\mathrm{v}$ urbanistični in arhitekturni stroki na vprašanja $z$ vidika širjenja in zgoščevanja mest, ohranjanja elementov krajine znotraj grajene strukture in zahtev sodobne urbane družbe. Nove urbane tipologije, kjer sta krajina in grajena struktura povezani $v$ celovito urbano območje, zadovoljujejo sodobne potrebe prebivalcev po javnih odprtih prostorih, ki so neposredno dostopni ob različnih urah čez dan.

Namen prispevka je predstaviti alternativne pristope $\mathrm{k}$ načrtovanju javnega odprtega prostora $\mathrm{z}$ vidika vključevanja krajinskih elementov v urbano strukturo. Predstaviti želimo, kako so načrtovalske paradigme trajnostnega razvoja in spremenjene družbene potrebe vplivale na načrtovanje in pojavnost javnih odprtih prostorov v sodobnih urbanih območjih.

Izhodišča in skupne lastnosti za opredelitev pojava hibridnega odprtega javnega prostora krajinskih elementov in grajene strukture $\mathrm{v}$ urbanih območjih so:

- program odprtega prostora in grajene strukture se na obravnavanem območju dopolnjujejo;

- grajena struktura in elementi krajine se na obravnavanem območju fizično prepletajo oziroma je krajina kot element vključena $\mathrm{v}$ načrtovanje urbane strukture;

- elementi krajine so izhodiščni material za načrtovanje obravnavanega urbanega območja oziroma za oblikovanje posamičnih objektov;

- obravnavano urbano območje je strateški instrument razvojne strategije mesta, saj prispeva $\mathrm{k}$ prepoznavnosti in programski pestrosti širšega območja urejanja ter izboljšuje kakovost bivanja.

S predstavljenimi alternativnimi oblikami javnega odprtega prostora in opredeljenimi metodološkimi izhodišči za načrtovanje predlagamo sodobne načine vključevanja elementov krajine $\mathrm{v}$ urbano strukturo pri celostnem urejanju urbanih območij. Cilj takšnega načrtovanja je enakovredna obravnava krajinskih elementov in grajene strukture pri načrtovanju razvoja urbanih območij.

\section{Nove tipologije grajene strukture $\mathrm{v}$ urbanem prostoru in njihov odnos do mestne krajine}

\subsection{Novi pristopi k načrtovanju urbanih območij}

Mesto ni le »prostor bivanja, ampak prostor, ki ga izoblikujejo njegovi prebivalci« (Balsley, 2000: 8), zato se je zaradi nezmožnosti prilagajanja novim družbenim potrebam v 80. letih 20. stoletja preoblikovalo v neorganizirani prostor. Procesi, kot sta nenadzorovano širjenje grajene strukture $\mathrm{v}$ zaledje mesta in praznjenje strnjenega mesta, so pripeljali do razpršenega mesta in izpraznjenega zgodovinskega mesta. Širjenje grajene strukture v zaledje mesta je izoblikovalo specifična središča $\mathrm{v}$ njem (stanovanjska območja individualne gradnje, nakupovalna središča, poslovna območja ...) in povzročilo praznjenje strnjenega oziroma zgodovinskega mesta (Koželj, 2001). Nastali so pojavi in problemi, kot so izguba človekovega merila, pomanjkanje kakovostnega javnega odprtega prostora, povečana raba avtomobila, pojav degradiranih območij in čezmerna izraba zemljǐ̌č. Proces širjenja grajene strukture $\mathrm{v}$ zaledje mesta oziroma proces urbane razpršitve pa se kljub kritičnemu stanju v prostoru ter novim strateškim izhodiščem razvojnih urbanih politik nadaljuje. Idealno bivalno okolje v očeh prebivalcev namreč ostaja individualni bivalni prostor v zaledju mesta, kjer imajo neposredni stik z odprto krajino. Obema modeloma mest, tako razpršenemu kot zgodovinskemu mestu (Koželj, 2001), je treba dati novo urbano vrednost, ki bo dvignila kakovost bivanja in sodobnemu prebivalcu omogočila raznovrstno izkustveno doživetje čez dan ter fizične stike in izmenjavo informacij.

V sodobni evropski urbanistični misli se vzporedno z novimi načrtovalskimi metodami razvoja mest, ki rešujejo problematiko stanja $\mathrm{v}$ urbanih območjih (krčenje mest in urbana razpršitev), odpira novo vprašanje $\mathrm{v}$ urbanistični stroki, in sicer $\mathrm{z}$ vidika premostitve nasprotij med ideologijo starega (strnjenega) in resničnostjo novega (razpršenega) mesta. "Nesmiselno je ohranjanje kompaktnega mesta $\mathrm{z}$ njegovimi trdno določenimi mejami. Prav tako bi bilo narobe vrednote starega mesta popolnoma pozabiti zaradi umetniško sanjaške sentimentalnosti, ki je značilna za periferijo. /.../ K staremu in novemu modelu mesta je treba poiskati produktivni nastavek« (Steiner, 2004; citirano v: Guallart, 2004: 10).

Novi pristopi $\mathrm{v}$ urbanističnem načrtovanju, kot so upoštevanje novih socialnih struktur in novih tehnoloških dosežkov, racionalna in ponovna raba prostora, varovanje odprtega prostora in poudarjanje pomena prisotnosti krajine $\mathrm{v}$ urbanih območjih, obnova, revitalizacija in zgoščevanje urbanega tkiva v nova identitetna območja mešanih rab, upoštevanje širšega konteksta prostora in prepoznavanje potencialov za razvoj ter vzpostavljanje prilagodljivosti in dinamičnosti v urbanih območjih so pripeljali do pojava takšnih tipologij urbane strukture, kjer sta krajina in grajena struktura obravnavani enakovredno. 
Kljub urbanističnim in arhitekturnim teorijam ter posamičnim izvedenim primerom, ki krajino in grajeno strukturo v urbanem prostoru obravnavajo enakovredno, pa se predvsem zaradi gospodarskih interesov investitorjev to ravnotežje na aplikativni ravni velikokrat poruši. Zato umeščanje zelenih površin v območje mesta največkrat izpodrine težnja po gradnji novih, tržno usmerjenih objektov, kar pa slabša kakovost bivanja. Zaradi pritiska na nepozidana območja in prisvajanja javnih površin $\mathrm{v}$ tržne namene se veliko parkov in drugih javnih odprtih prostorov manjša ali celo izginjajo. Na drugi strani pa v mestu lahko opazimo tudi območja odprtih prostorov, ki so zapuščena oziroma še neizkoriščena zemljišča. Skupni problem zapuščenih javnih odprtih prostorov je, da v preteklosti niso bili prilagojeni potrebam prebivalcev, torej niso služili svojemu namenu. Oba pojava izginjanja javnega odprtega prostora $\mathrm{v}$ mestnih območjih sta posledica pretekle urbanistične prakse, ko so bile predvsem zelene površine $\mathrm{v}$ mestu obravnavane kot antiteza mestu in kot neekonomični element mestnega razvoja. Območja zelenih površin so bila v preteklosti $\mathrm{v}$ občinskih prostorskih aktih obravnavana kot kvantitativni element, brez strateško določenega pomena za razvoj območja urejanja in brez določenih kakovostnih ter programskih usmeritev za načrtovanje javnih odprtih prostorov. Tako se je pomen zelenih površin v mestu popolnoma oddaljil od prvotnega pomena javnega parka v 19. stoletju, namreč da park v mestu prispeva $\mathrm{k}$ njegovemu gospodarskemu razvoju, saj spodbuja zdravo življenje prebivalcev. Zelene površine so proti koncu 60. let 20. stoletja postale le še blažilec podobe grajene strukture stolpičev in cest.

V vsakodnevnem življenju prebivalcev se pojavljajo nove potrebe in vrednote, kot so delo na domu, kakovostno preživljanje prostega časa, stik z naravo, hiter dostop do informacij in storitvenih dejavnosti ter prepletanje človekovih aktivnosti (delo, bivanje in preživljanje prostega časa) čez dan. Tradicionalna družba skupnih vrednot in univerzalnih potreb se je zaradi novih možnosti bivanja in dela ter stopnje tehnološkega napredka preoblikovala v kompleksno pluralno družbo raznovrstnih potreb. Delo sodobne družbe temelji na znanju in ni prostorsko omejeno. Nove potrebe in vrednote prebivalcev zahtevajo nova kakovostna bivalna okolja, kar vpliva na preoblikovanje urbanih območij. Izhodišča za njihovo načrtovanje niso več splošni vzorci družbe, ampak potrebe posamičnih skupin. Kakovostno bivalno okolje ustvarjata tako notranji zasebni prostor bivanja in dela kot zunanji odprti javni prostor $\mathrm{v}$ okolici, zato nove potrebe in vrednote prebivalcev zahtevajo tudi spremembe $\mathrm{v}$ načrtovanju javnega odprtega prostora.

\subsection{Pomen javnih odprtih prostorov v urbanih območjih}

Javni odprti prostor je eden izmed očitnejših odrazov družbe $\mathrm{v}$ mestu in odgovor na družbeno realnost sedanjega časa. Obsega območja zelenih površin (površine za rekreacijo in šport, parki, druge zelene površine in pokopališča) in območja drugih javnih odprtih prostorov (trgi, ploščadi pred javnimi objekti, tržnice, ulice, utrjene obale ali bregovi, pasaže in podhodi) (Prostorski red Slovenije, Ur. 1. RS, št. 122/2004). Javni odprti prostor je bistven za kakovost življenja v mestu, saj omogoča komuniciranje in srečevanje med ljudmi, oddih in rekreacijo na zraku, javno življenje ter uravnavanje mikroklime. Zaradi socialnih, ekoloških, morfoloških in strukturnih funkcij v načrtovanju urbanih območij je javni odprti prostor kritični medij za kulturno izražanje, prepoznavnost prostora, vključevanje trajnostnih meril in gospodarski razvoj urbanih območij.

Glavna prednost pri načrtovanju sodobnega javnega prostora, ki postavlja kakovost pred kvantiteto, je zagotavljanje čim različnejših možnosti uporabe javnega prostora, ki ustrezajo različnim življenjskim navadam prebivalcev ter tako dopolnjujejo oziroma nadgrajujejo mestne programe. Krajinski fragmenti urbanega sistema so kontinuum oziroma podaljšek bivalnega in delovnega prostora ter so prilagojeni posameznim potrebam skupnosti, s čimer območje pridobiva kakovost bivanja, programsko pestrost in javno potrošnjo (Koželj, 1996). Prepoznavanje potencialov in priložnosti, ki jih ponuja javni odprti prostor v določenem razvojnem območju, ter primerno vključevanje krajinskih elementov v urbano strukturo povečujeta zanimanje novih investitorjev in potencialnih prebivalcev, kar krepi lokalno ekonomijo določenega urbanega območja.

\subsection{Krajina kot integralni del grajene strukture}

Krajinski arhitekti, arhitekti in urbanisti razvijajo predloge razvijajo predloge oblikovane mestne krajine, ki nadomestijo pomanjkanje alternativnih oblik javnega prostora, da bi znova vzpostavili kompaktnejšo grajeno strukturo. Eden glavnih in najpomembnejših strateških ciljev za usmerjanje razvoja $v$ strnjenem in razpršenem mestu je enakovredna obravnava krajinskih elementov in grajene strukture. Krajinski elementi so regulacijsko orodje za preoblikovanje tako razpršenega kot strnjenega mesta. Preplet krajine in grajene strukture omogoča preplet različnih rab v prostoru in različne možnosti 
uporabe javnega odprtega prostora, ki ustrezajo sodobnemu urbanemu življenju prebivalcev. Znova je treba razmisliti o odnosu med grajeno in krajinsko strukturo oziroma o gostoti grajene strukture in oblikah odprtega prostora. V svojem delu vzpostavljajo dialog med tradicionalno ločenima pojmoma zgradba in krajina, ki dovoljuje sočasno prisotnost enega $\mathrm{v}$ drugem; zgradba kot krajina, krajina kot zgradba:

"After 'urbia' came 'suburbia' comes 'nonurbia'... Predstavljamo vam novi ruralni arhetip, ki je zlitje krajine in urbane gostote. Cisti destilat kompleksne prostorske strukture mestnega centra, transplantiran v krajino /.../Hiša z vrtom postane hiša s krajino. Veliko ljudi želi živeti zdravo in hkrati moderno, z dostopom do odprtega prostora in svežega zraka /.../Bivanje, delo, rekreacija in potrošnja se prekrivajo in dopolnjujejo." (Timmermans in Godefroy, 2000: 21-23).

$\mathrm{V}$ preteklosti so parki povsem prevladovali $\mathrm{v}$ mestnih ureditvah. Zdaj se jih načrtuje $» \mathrm{~V}$ povezavi $\mathrm{Z}$ drugo rabo v prostoru « (Turner, 1996: 5). Parki v sodobnem mestu niso več posamična izolirana območja, ki so dostopna le po prometnih poteh, ampak območja, ki programsko dopolnjujejo notranji bivalni in delovni prostor. "Namesto parka kot takega je park prostor dogodka in akcije, ki izboljšuje in dopolnjuje mesto" (Tschumi, 1995: 16). Sodobni parki so zasnovani kot območja, ki so soodvisna od značilnosti širšega območja, v katerem ležijo in so temu prilagojeni ter so pomemben gradnik urbane strukture. Vključevanje krajinskih elementov v grajeno strukturo zdaj izoblikuje nove urbane tipologije, ki odpravljajo mejo med mestom in odprtim prostorom, med grajeno strukturo in krajino.

V nadaljevanju prispevka je predstavljen projekt širitve pozidave $\mathrm{v}$ Valencii, poimenovan Sociopolis, kjer je načrtovalcem $\mathrm{z}$ inovativnim vključevanjem krajinskih elementov $\mathrm{v}$ novo urbano strukturo uspelo izoblikovati sodobni urbani življenjski prostor, ki ustreza sodobnim družbenim skupinam in upošteva sodobna spoznanja o okolju.

\section{Projekt Sociopolis}

Urbanistični načrt Sociopolis, katerega generalni vodja je bil Vicente Guallart, razvije novo podobo mesta, ki vključuje najnovejšo tehnologijo gradnje

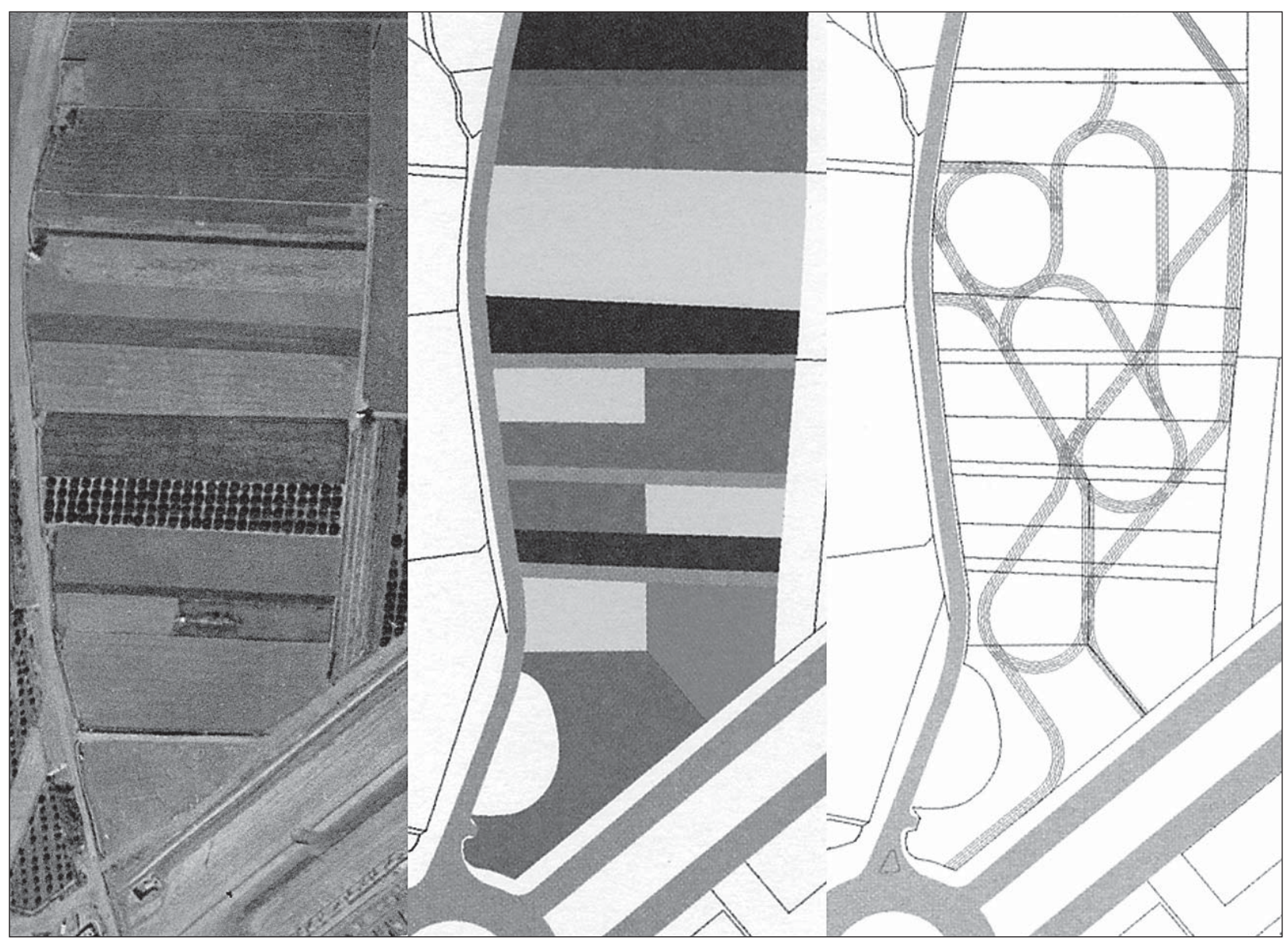

Slika 1: Projekt Sociopolis. (Vir: Guallart, 2004: 28-30) 
in informacijsko tehnologijo ter stare vrednote mešanih območij in nove stanovanjske oblike za sodobne družbene skupine. Vodilni moto projekta je »moj dom je moje sosedstvo, moje sosedstvo je moj dom« (Guallart, 2004: 23), kar pomeni, da vsak objekt poleg bivanja vključuje še neko drugo dejavnost. Celotno območje, kjer naj bi v prihodnosti bivalo 3000 prebivalcev, deluje kot mikromesto, saj omogoča zaposlovanje, vzpostavlja celotno infrastrukturo ter zagotavlja socialne servise in javni odprti prostor. Dietmar Steiner (prav tam: 10), direktor dunajskega arhitekturnega centra, kjer je bil projekt decembra 2004 predstavljen na simpoziju, Sociopolis opiše kot "produktivni nastavek k staremu in novemu modelu mesta«. Vicente Guallart išče s projektom za mesto prihodnosti sintezo med družbenimi potrebami, urbanim redom in trajnostnimi merili.

Načrtovalci območja ob analiziranju družbenih vrednot ne iščejo več splošnih vzorcev celotne družbe, kakor je bilo značilno za modernistično obdobje. Vrednote prihodnjih uporabnikov, ki so za načrtovalce eno od temeljnih izhodišč pri načrtovanju sodobnega mestnega prostora, so združene glede na potrebe posamičnih skupin. Cilj projekta je zagotoviti primerno bivalno okolje »za mlade ljudi, ki se želijo osamosvojiti, za starejše ljudi, ki želijo živeti sami, in za prebivalce, ki so prišli iz drugih držav, ter ljudi, ki so vključeni v posebne socialne programe. Vse te socialne skupine so namreč pomemben del naše družbe« (prav tam: 16).

Pri širitvi pozidave na obstoječa kmetijska zemljišča ne gre za običajni urbanistični pristop širitve, ki izpodrine primarno rabo, ampak za integracijo obstoječe krajine v na novo grajeno strukturo tako $\mathrm{s}$ programskega in pomenskega vidika kot $\mathrm{z}$ vidika same pojavnosti v urbani strukturi. Sociopolis odpravlja meje med mestom in krajino, pri čemer v mestno strukturo vključuje celo kmetijske dejavnosti. Guallart označi obstoječo krajino kot ključni element prepoznavnosti in razvoja mesta Valencie v času globalizacije. Urbanistična zasnova območja ohranja elemente krajine in sledi obstoječi topografiji oziroma parcelaciji kmetijskih zemljišč.

Rešitev predlaga nekonvencionalni projekt, ki združuje različne vidike, ki naj bi v prihodnosti oblikovali kakovostno bivalno okolje oziroma sodobni Življenjski prostor:

- kakovostna gradnja po dosegljivih cenah,

- urbana struktura, ki omogoča harmoničnost bivanja različnih socialnih skupin,

- oblikovalska svoboda arhitektov,

- celotni program mesta,

- upoštevanje trajnostnih meril, ki združujejo urbano rast in varovanje obstoječe krajine.
V mikromestu, ki vključuje večino mestnih funkcij in kjer prebivalci preživijo polovico časa, njihovo gibanje sledi načelom "počasne soseske» (prav tam: 27). Bližina različnih dejavnosti omogoča, da je motorni promet izključen. Parkirišče je na robu sosedstva. Peš in kolesarski promet potekata na tako imenovani atletski stezi, ki je dvignjena ploščad nad krajino in povezuje posamična območja v sosedstvu. Guallart označi idejo športa kot primarno dejavnost za interakcijo med ljudmi. Posebnost urbanističnega projekta je, da ne predvidi gabaritov objektov, kar naj bi spodbujalo načrtovanje posamičnih objektov. Vsakemu arhitektu so podani le program, parcela in potek infrastrukture, zato obstoječo krajino zelo različno integrirajo v območje urejanja in objekte. Trinajst arhitektov oziroma skupin, ki so pripravili projekte za posamične objekte, je: Vincent Guallart

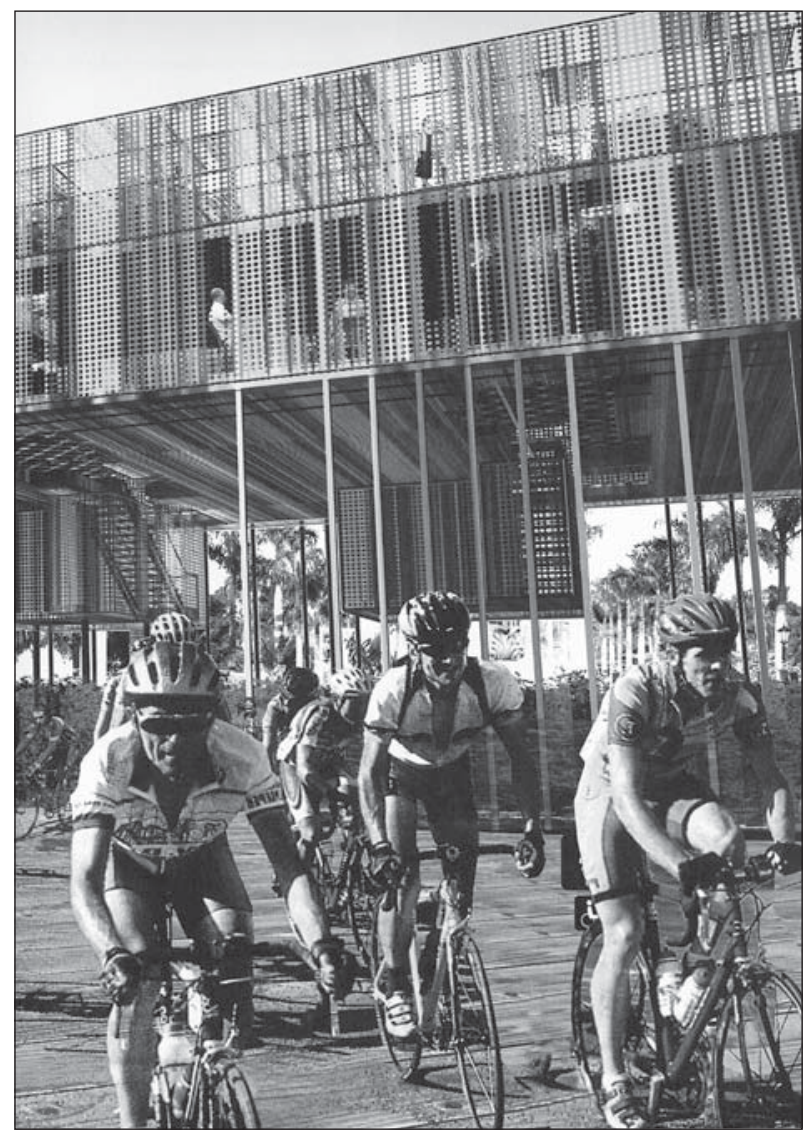

Slika 2: Duncan Lewis Scape Architecture in BLOCK: Objekt zavzame celotno območje parcele, pri čemer je pritličje večinoma nepozidano in posajeno s pomarančevci. Ta prostor je dostopen ne le prebivalcem objekta, ampak celotni soseski Sociopolisa. Pomarančevci so zasajeni tudi v drugem nadstropju. Zadnje, tretje nadstropje je namenjeno skupni rabi, sprostitvi in razvedrilu prebivalcev. Čeprav celotna struktura objekta na zunaj daje vtis kompaktnega volumna, je zasnovana iz lebdečih volumnov, ki se izogibajo krošnjam pomarančevcev $v$ notranjosti in tako ustvarjajo hibridno strukturo krajinskih in grajenih elementov oziroma odprtih in zaprtih prostorov ter skupnih in zasebnih prostorov. (Vir: Guallart, 2004: 143) 
in Maria Diaz, Abalos \& Herreros, Greg Lyn Form, FOA, Jose Maria Torres Nadal, Manuel Gausa, Duncan Lewis Scape Architecture in BLOCK, WMA Willy Müller, Sogo, MVRDV, No.MAD, Toyo Ito Associates, R\&Sie.

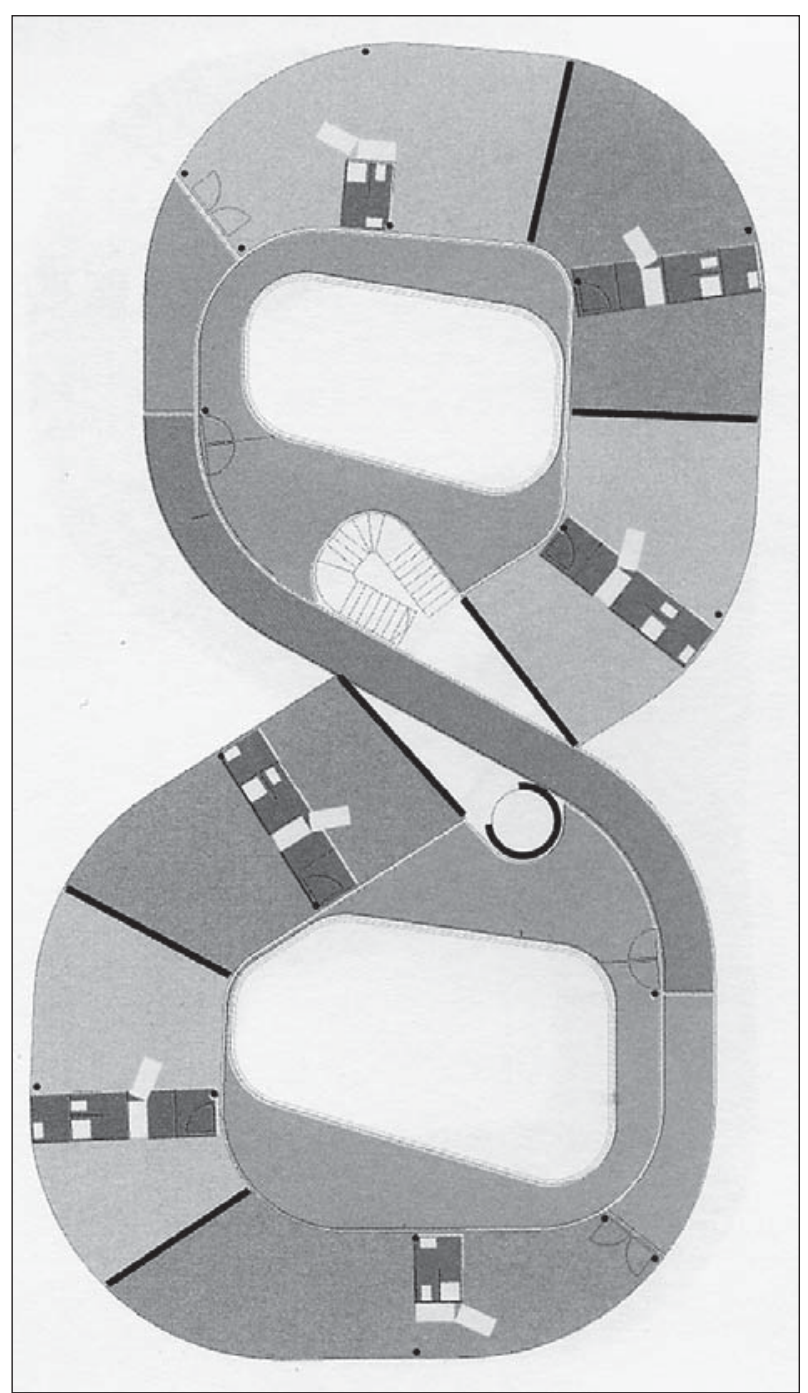

Slika 3: Jose Maria Torres Nadal: Zahtevana urbanistična izhodišča po vključevanju krajine v območje ureditve so uresničena z oblikovanjem notranjih dvorišč, ki so razporejena po vertikali objekta. (Vir: Guallart, 2004: 104)
Da gre za nov pristop v načrtovanju urbanega prostora, ki oblikuje novo tipologijo, ki ni ne krajina ne grajena struktura, ponazarja opis sodelujočega arhitekta Toya Ita (prav tam: 211-222), s katerim predstavi svoj projekt: »Od nekdaj sem si želel uresničiti arhitekturo, ki je bliže vrtu kot objektu. /.../ Uporaba novih tehnologij in materialov nam je omogočila oblikovanje mehkega prostora, ki deluje kakor obleka. /.../ Ob lepem vremenu se celotni objekt spremeni v odprti prostor oziroma zunanji prostor objekta /.../S projektom smo želeli ustvariti nekaj, kar omogoča izmenjavo z zunanjim prostorom in stike med ljudmi.«

Pri iskanju rešitev za ustvarjanje privlačnega, vitalnega in kakovostnega bivalnega okolja je obstoječa krajina za arhitekte izhodiščni material za oblikovanje posamičnih objektov oziroma celotnega območja urejanja. Elemente krajine so v projektih opredelili kot strukturo, ki je fizično in programsko povezana $\mathrm{z}$ grajeno strukturo $\mathrm{v}$ neločljivo kompleksno celoto. Rezultat takšnega pogleda na načrtovanje je prepoznavna oblikovalska zasnova krajine, ki je del kulturne podobe urbanega območja in deluje kot sestavina javnega in odprtega prostora. Celotno območje je nekakšen park, v katerem prebivalci bivajo, delajo, se izobražujejo, družijo med seboj, preživljajo prosti čas in celo pridelujejo hrano.

\section{Hibridni odprti javni prostor krajinskih elementov in grajene strukture}

Javni odprti prostor v primeru Sociopolisa je urbani park, $v$ katerem so elementi krajine fizično in programsko prepleteni $z$ grajeno strukturo. Načrtovalci so $\mathrm{z}$ novimi pristopi $\mathrm{k}$ načrtovanju urbanega prostora izoblikovali nove tipologije $\mathrm{v}$ urbanem prostoru, kjer so grajena struktura, elementi krajine in program povezani v kompleksno urbano strukturo,

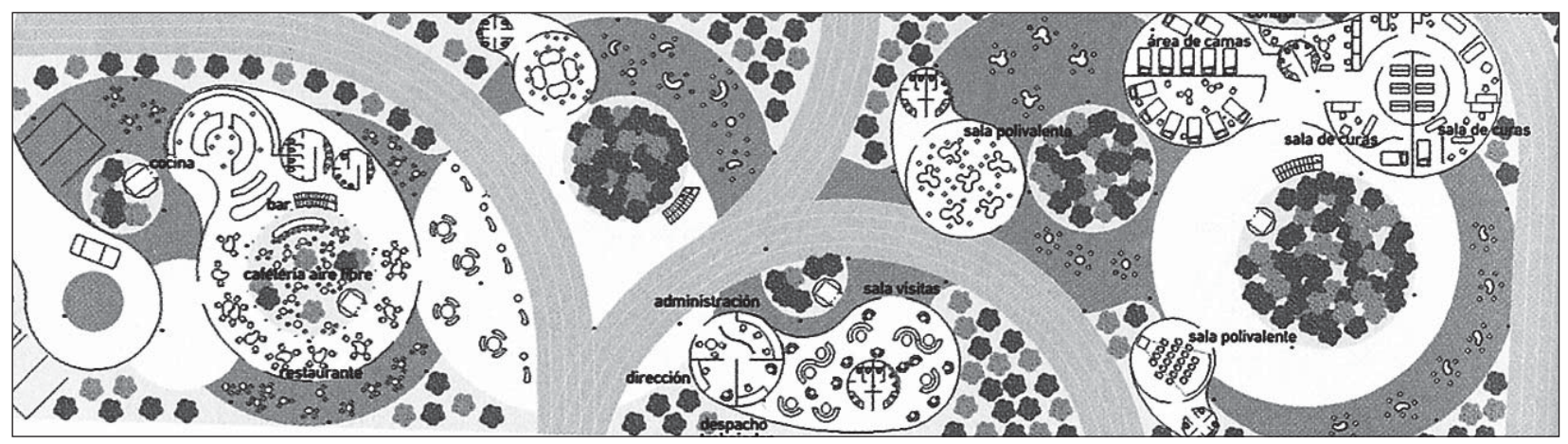

Slika 4: Toyo Ito Associates. (Vir: Guallart, 2004: 216) 
ki ni le krajina ali grajena struktura, ki ni ne eno ne drugo. Oblikovana krajina ni le območje, ki programsko dopolnjuje druge funkcije (mestotvorne dejavnosti) v urbanih območjih, ampak je tudi fizično povezana $\mathrm{z}$ grajeno strukturo $\mathrm{v}$ neločljivo celoto. V urbanem parku Sociopolisa so združene vse človekove celodnevne funkcije, zato te oblike javnega odprtega zelenega prostora ne moremo enačiti $\mathrm{s}$ tradicionalnim pojmom parka $\mathrm{v}$ mestu.

Sodobna oblika javnega odprtega prostora se v urbanem območju pojavlja kot urbani park, kjer so elementi krajine fizično in programsko vključeni v kompleksno urbano strukturo. Krajinski elementi so izhodiščni material za oblikovanje posamičnih objektov oziroma za načrtovanje določenega urbanega prostora. $\mathrm{V}$ hibridnem odprtem javnem prostoru se prepletajo elementi krajine in grajene strukture ter različne rabe prostora. Elementi krajine s svojim programom (oddih in rekreacija ter doživljanje kulturnih, izobraževalnih in socialnih prizorišč) dopolnjujejo program grajene strukture. Fizična in programska prepletenost krajinskih elementov in grajene strukture omogoča uporabnikom tega prostora različne dnevne rabe, kot so oddih in rekreacija ter doživljanje drugih prizorišč (kulturnih, izobraževalnih in socialnih), v pretežno s krajinskimi elementi urejenem odprtem javnem prostoru. Hibridni javni odprti prostori dodajajo nove oblike javnega odprtega prostora $\mathrm{k}$ znanemu repertoarju, kot so trg, ulica in park. Tradicionalna oblika parka $v$ mestu torej ostaja.

Sodobne oblike javnega odprtega prostora so po svoji obliki in programu zelo različne, se pa $\mathrm{v}$ urbanem območju pojavljajo v obliki hibridizacije parka ter različnih tipov grajene strukture, kot so stanovanjske enote, javne zgradbe, industrijski objekti in drugi objekti. Programska in fizična prepletenost različnih oblik grajene strukture z elementi krajine vpliva na to, da se $\mathrm{v}$ urbanem prostoru pojavljajo različne oblike hibridnih odprtih javnih prostorov tako $\mathrm{z}$ vidika programa, ki ga ponujajo uporabnikom, kot $\mathrm{z}$ vidika pojavnosti $\mathrm{v}$ urbanih območjih. $\mathrm{Na}$ podlagi rezultatov, ki so bili pridobljeni $\mathrm{z}$ analizo primerov pojava hibridnega javnega odprtega prostora in njihove medsebojne primerjave ter prepoznavanja določenih skupnih značilnosti, so bile $\mathrm{v}$ raziskavi opredeljene naslednje oblike hibridnih odprtih javnih prostorov:

- stanovanjska krajina: kompaktno zgoščanje goste stanovanjske gradnje in krajine oblikuje novo tipologijo goste stanovanjske gradnje $\mathrm{v}$ interakciji s skupnimi zelenimi površinami;

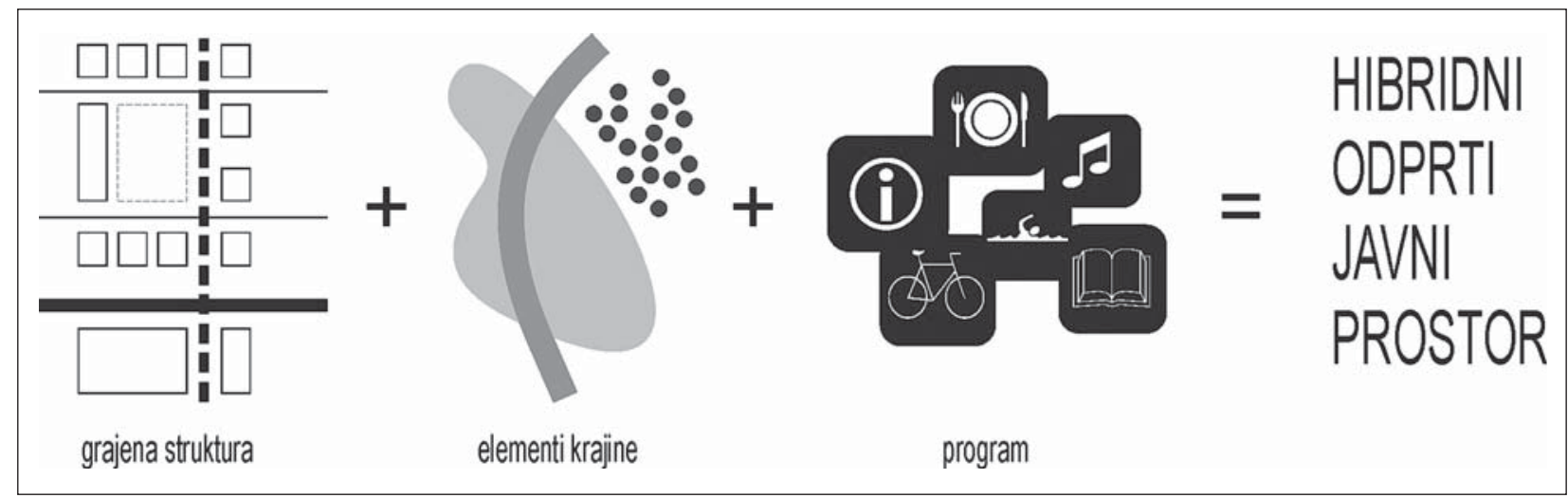

Slika 5: Hibridni odprti javni prostor krajinskih elementov in grajene strukture.

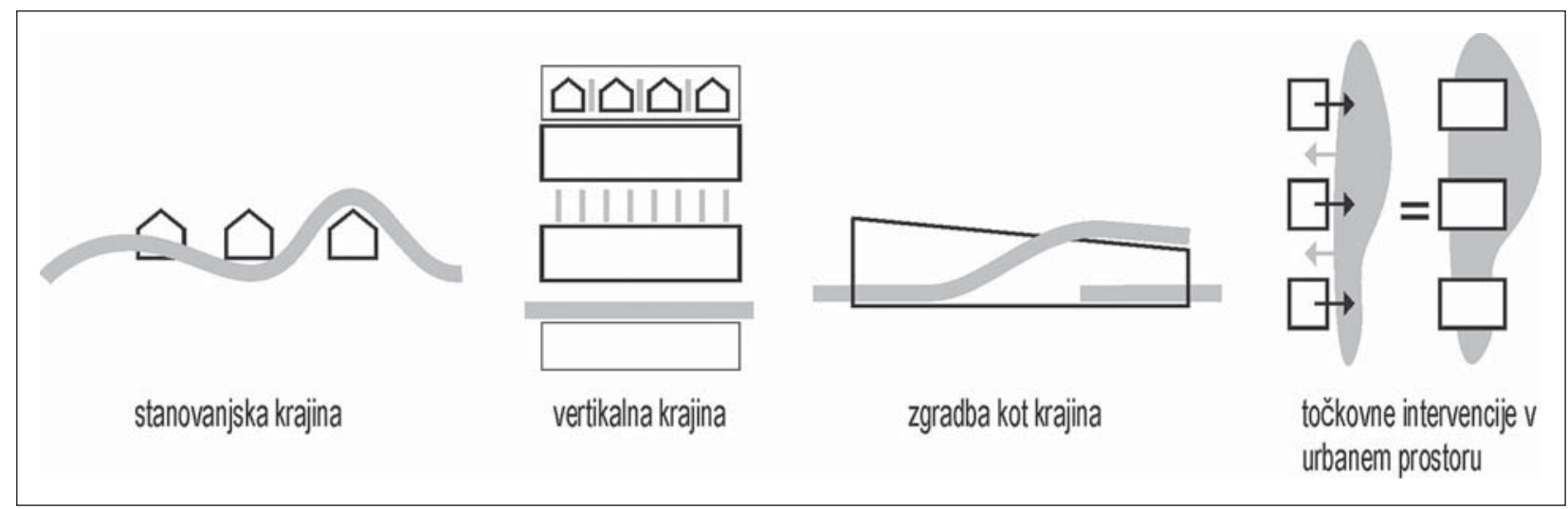

Slika 6: Oblike hibridnih odprtih javnih prostorov. 


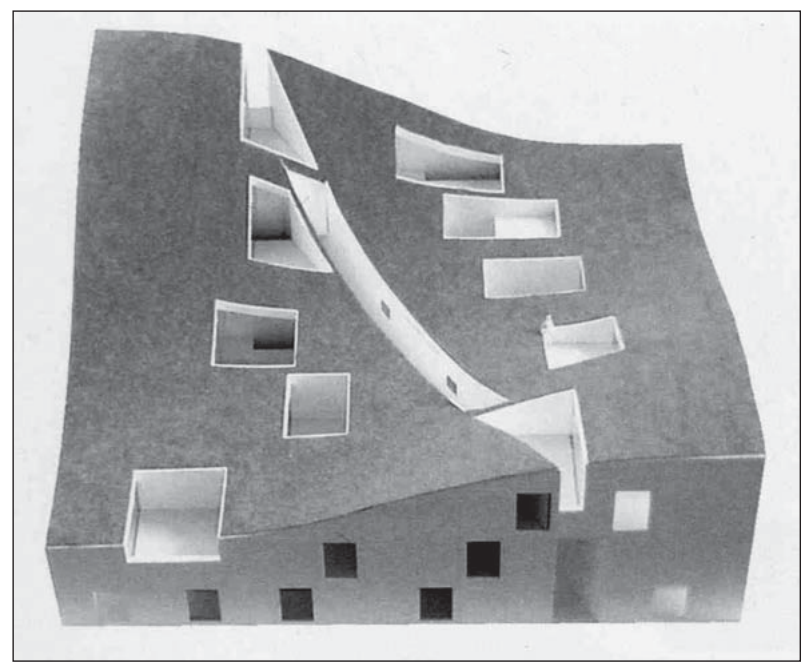

Slika 7: Stanovanjska krajina: Skupina NL Architects - Funen Blok K v Amsterdamu, 2005. (Vir: La Biennale di Venezia, 2004a: 178)

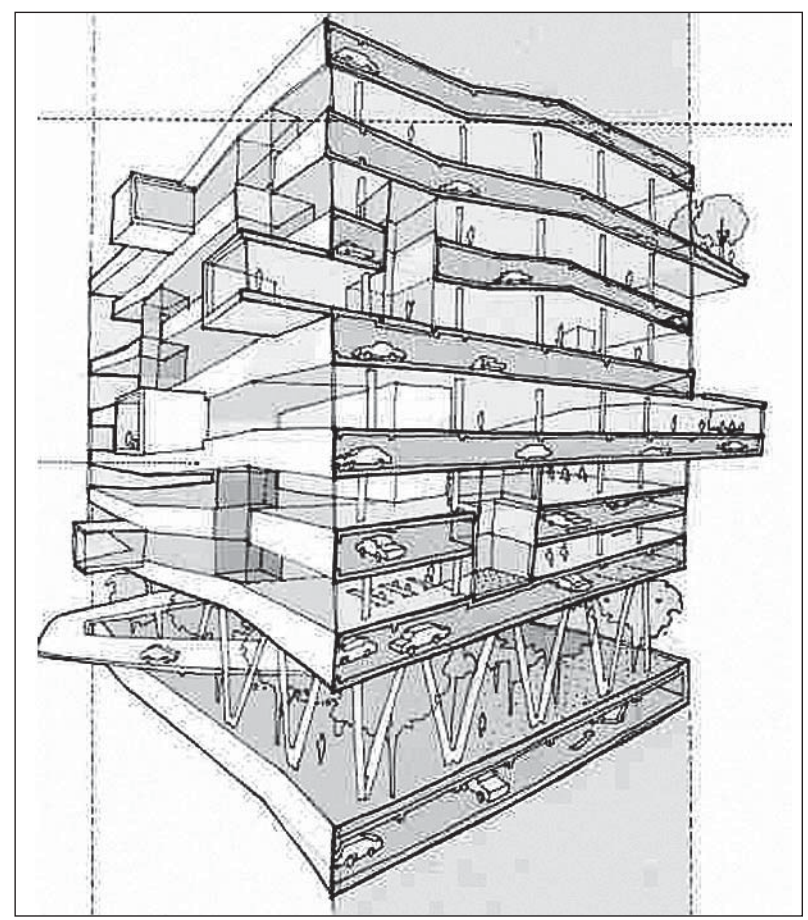

Slika 8: Vertikalna krajina: Lewis.Tsurumaki.Lewis ParkTower v New Yorku, 2004. (Vir: La Biennale di Venezia, 2004b: 119)
- vertikalna krajina: elementi krajine so v različnih nadstropjih po prerezu grajene strukture;

- zgradba kot krajina: krajinski elementi in topografska prilagoditev grajene strukture krajinskim elementom omogočajo racionalno gradnjo prostora in oblikujejo zvezno urbano strukturo brez trdno določenih meja med notranjim in zunanjim prostorom;

- točkovne intervencije: aktiviranje novih urbanih kvalitet $\mathrm{z}$ vnosom krajinskih elementov v urbani prostor.

Iz sklepov raziskave - medsebojne primerjave ugotovitev in splošnih zakonitosti ter sintetiziranja podatkov o pojavu hibridnih struktur v urbanem prostoru - so bila oblikovana metodološka izhodišča za načrtovanje hibridnega javnega odprtega prostora. Da bi v območju urejanja znova dosegli primerno stopnjo urbanosti, kakovostno bivalno okolje in prepoznavnost $\mathrm{v}$ prostoru ter da bi umestitev hibridnega odprtega javnega prostora $v$ območje urejanja prispevala h gospodarskemu razvoju širšega območja in zadovoljevanju sodobnih potreb prebivalcev, je treba pri načrtovanju hibridnega odprtega javnega prostora upoštevati naslednje usmeritve:

- da se ga umešča predvsem v degradirana ali zapuščena oziroma za rabo še neizkoriščena območja

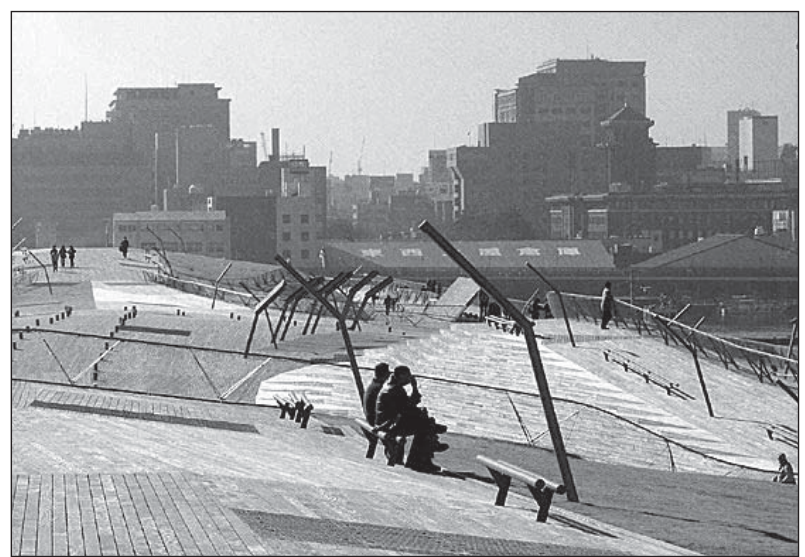

Slika 9: Zgradba kot krajina: Foreign Office Architects International Port Terminal v Jokohami, 1996. (Vir: Cecilia in Levene, 2003: 79)

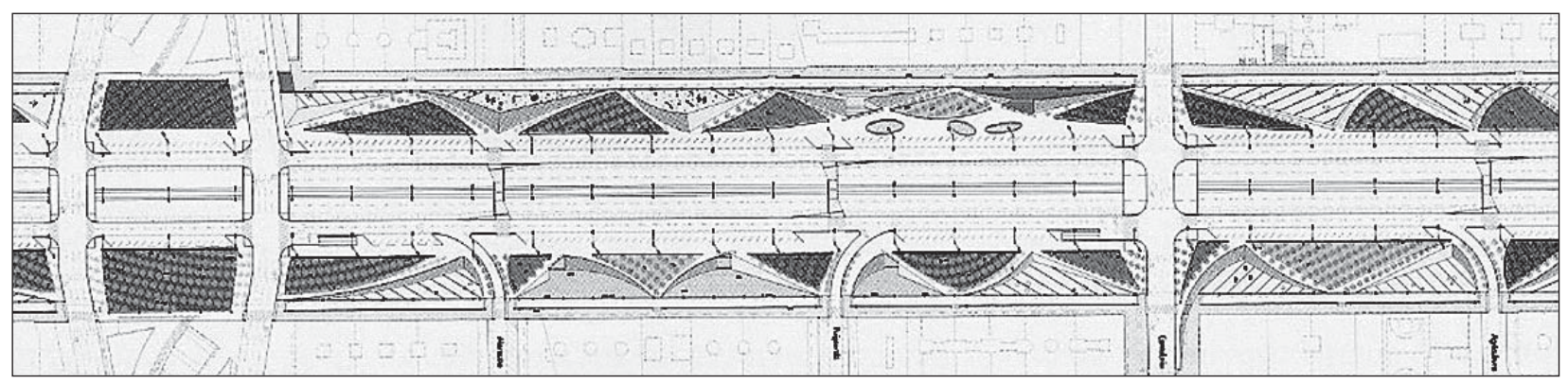

Slika 10: Točkovne intervencije: Andreu Arriola in Carme Fiol - preoblikovanje ulice Gran Via v Barceloni, 2004. (Vir: Mestre in Beredo, 2004: 100) 
$\mathrm{v}$ strnjenem mestu in $\mathrm{v}$ območja specializiranih središč $\mathrm{v}$ razpršenem mestu;

- da se ga poveže v sistem krajinskih koridorjev in odprtega javnega prostora;

- da krajinski elementi v območju urejanja z grajeno strukturo oblikujejo kompleksno območje, torej da s svojim programom (aktivnosti v odprtem zelenem prostoru, kot so druženje, rekreacija in kulturni dogodki) nadgrajujejo in dopolnjujejo program grajene strukture in so fizično neposredno povezani z grajeno strukturo;

- da se upoštevajo želje in potrebe prihodnjih uporabnikov ter težnje $z$ vidika gospodarskega razvoja, ki so v načrtovanju potenciali za razvoj;

- da se zagotovita dinamičnost in prilagodljivost rab na območju urejanja oziroma se omogočijo začasne rabe;

- da so značilnosti obstoječe grajene in krajinske strukture izhodišče za načrtovanje in razvoj območja urejanja;
- da se ohranja avtohtonost krajine ali se jo na novo ustvarja;

- da se z umeščanjem krajinskih elementov v območje urejanja oblikuje primerna mikroklima za bivanje (ponuja hladen in senčen prostor, osončen prostor ...).

Umeščanje hibridnih odprtih javnih prostorov v vmesne in robne prostore urbanih območij izboljšuje stanje $\mathrm{v}$ prostoru oziroma prispeva h kakovosti bivanja, povečuje pestrost ponudbe in vpliva na razvoj širše okolice. Krajinski elementi in grajena struktura se v hibridnem javnem odprtem prostoru programsko dopolnjujejo in šele skupaj ustvarjajo celovito urbano obliko, ki zadovoljuje sodobne potrebe urbanega življenja prebivalcev. Skupno izhodišče vseh pristopov je preoblikovanje danih prostorskih in družbenih možnosti v inovativne rešitve urbanih območij. Hibridni odprti javni prostor v načrtovanju urbanih območij je strateški instrument za razvoj in obnovo urbanih

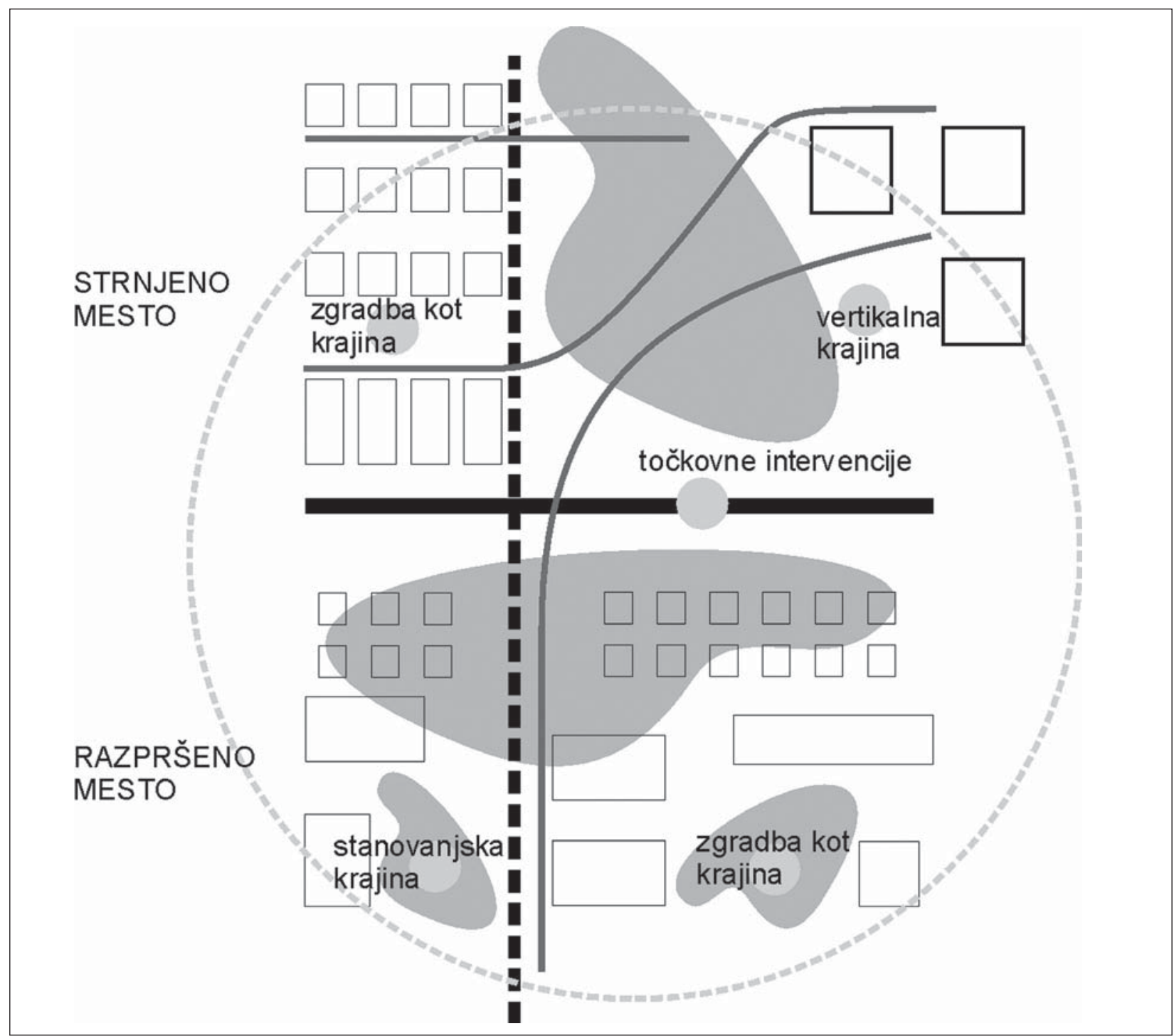

Slika 11: Hibridni odprti javni prostor kot strateški instrument za razvoj in obnovo urbanega območja. 
območij. Načrtovalce zanimajo predvsem delovanje in odnos elementov v območju urejanja in učinek na razvoj širšega območja $v$ času. Ustvarjanje kompleksnih in uporabnih urbanih območij pa zahteva bolj organizirano in strateško strokovno znanje, in ne le formalnega znanja o kompoziciji in reprezentativnosti. Pri načrtovanju novih oblik javnega odprtega prostora gre torej za premik od načrtovalskega pristopa, ki območje izboljšuje oziroma oblikuje samo z vidika pojavnosti in scenskosti, $\mathrm{k}$ pristopu, ki z upoštevanjem sodobnih potreb uporabnikov urbanega prostora in uporabo novih načrtovalskih metod produktivno prispeva $\mathrm{k}$ razvoju mesta in posameznika ter spodbuja razvoj kakovostnega bivalnega okolja (Corner, 1999). Zdaj umeščanje elementov krajine $\mathrm{v}$ urbano strukturo prevzema funkcijo povezovanja grajene strukture in revitalizacije razpršenega ter strnjenega mesta. Elementi krajine so skupaj z grajeno strukturo nova programska in razvojna vozlišča $\mathrm{v}$ sodobnem urbanem prostoru.

\section{Sklep}

Načrtovanje javnega odprtega prostora postaja čedalje pomembnejše, saj je pomen oziroma potreba po vzpostavljanju kakovostnega odprtega prostora opredeljena tudi $\mathrm{v}$ večini strateških prostorskih dokumentov, ki usmerjajo razvoj evropskih mest $\mathrm{k}$ trajnostnim ciljem. Med njimi je tudi Slovenija, ki je od osamosvojitve do danes na novo oblikovala zakonski okvir za prostorsko načrtovanje, kjer je prav tako poudarjen pomen javnega odprtega prostora v urbanih območjih za doseganje ciljev trajnostnega razvoja mest. $\mathrm{V}$ prihodnosti naj ne bi bile te površine $\mathrm{v}$ prostorskih aktih na ravni občine več obravnavane kot površine, ki jih je treba zagotoviti le s kvantitetnega vidika, kot je njihov delež $\mathrm{v}$ urbani strukturi. V prostorskih dokumentih na ravni države so podane tudi usmeritve načrtovanja in oblikovanja javnega odprtega prostora, ki naj bi jih arhitekti, krajinski arhitekti in urbanisti upoštevali pri celostnem urejanju urbanih območij, kot so gradnja na novih površinah, sanacija razpršene gradnje in celovita prenova naselij.

Z osvetlitvijo pojava in podanimi metodološkimi izhodišči za načrtovanje hibridnega javnega odprtega prostora krajinskih elementov in grajene strukture, ki so rezultat raziskovalnega dela $\mathrm{v}$ magistrski nalogi, razširjamo izhodišča za oblikovanje meril in pogojev v novi generaciji prostorskih aktov in urbanističnih načrtov, ki jih pripravljamo v Sloveniji. Kakovostna merila in pogoji za načrtovanje sodobnega javnega odprtega prostora bodo odločilno vplivali na kakovost bivalnega okolja v Sloveniji.
S pojavom hibridnega javnega odprtega prostora ne nadomeščamo znanega repertoarja elementov klasičnega mestnega prostora, ampak ga razširjamo. Čeprav se urbani park krajinskih elementov in grajene strukture umešča tudi v strnjeno mesto, je pojav povezan predvsem $\mathrm{z}$ načrtovanjem $\mathrm{v}$ različnih urbanih prostorih in $\mathrm{s}$ procesi načrtovanja $\mathrm{v}$ razpršenem mestu, degradiranih območjih in urbanih regijah. Povezan je s pojavi, kot so reurbanizacija, centralizacija robov mesta, zgoščanje razpršene gradnje in renaturalizacija industrijskih območij.

Hibridni odprti javni prostor s svojo hibridno strukturo krajinskih elementov in grajene strukture ter različnih rab nadgrajuje dosedanje tipologije javnih odprtih prostorov ter prispeva $\mathrm{k}$ ponovnemu vzpostavljanju urbanosti in kakovostnega bivalnega okolja. Hibridni odprti javni prostor je v urbanističnem načrtovanju strateški instrument, ki prispeva k prepoznavnosti določenega območja, programsko nadgrajuje grajeno strukturo in izboljšuje kakovost bivanja.

Mag. Gordana Bence, univ. dipl. inž. arh.

E-pošta: gordana.bence@gmail.com

\section{Viri in literatura}

Balsley, T. (2000) Thomas Balsley, The Urban Landscape. Berkeley, Spacemaker Press.

Cecilia, F., M. in Levene, R. (ur.) (2003) Yokohama International Port Terminal. Elcroquis - Foreign Office Architects (1996-2003), 115/116(1), str. 42-83

Corner, J. (ur.) (1999) Recovering Landscape - Essays in Contemporary Landscape Architecture. New York, Princeton Architectural Press.

Guallart, V. (2004) Sociopolis - Projekt für eine Stadt der Zukunft. BarceIona, Actar.

Internet 1: http://www. latzundpartner.de (sneto 10. 1. 2005)

Koželj, J. (1996) Ali so novi urbani vrtovi zametki renaturacije mest?, v: Hudoklin, J. (ur.) Urejanje odprtega prostora v urbanem okolju. Ljubljana, Društvo krajinskih arhitektov Slovenije.

Koželj, J. (2001) Temeljne strateške usmeritve, v: Čerpes, I. (ur.) Priporočila za urejanje naselij. Ljubljana, Univerza v Ljubljani, Fakulteta za arhitekturo - Inštitut za arhitekturo in prostor.

La Biennale di Venezia (2004a) Metamorph - Trajectories. Venezia, Marsilio.

La Biennale di Venezia (2004b) Metamorph - Vectors. Venezia, Marsilio. Mestre, J. in Beredo, I. (ur.) (2004) Remodeling the Gran Via. Quaderns, 240, str. 100-102.

Prostorski red Slovenije. Ur. I. RS, št.122/2004. Ljubljana.

Timmermans, M. in Godefroy, P. (2000) Jedem Haus seine Landschaft. Topos, 31, str. 17-23.

Tschumi, B. (1995) Event - Cities: Praxis. Cambridge, Mass., London, The MIT Press.

Turner, T. (1996) City as Landscape - A Post-postmodern View of Design and Planning. London, E\&FN Spon. 